\title{
UTILIZATION OF DEFATTED BALADI ORANGE PEEL IN PRODUCTION OF LOW CALORIC SPONGE CAKE \\ Ammar, A. K. ${ }^{1}$ and Mervat E. Eldemary ${ }^{2}$ \\ 1- Food technology Department, Faculty of Agric. Kafrelsheikh Univ. \\ 2-Home Economic Department, Faculty of Specific education. Kafrelsheikh Univ.
}

\begin{abstract}
Consumers are increasingly aware of diet related with health problems and those demanding natural products which are expected to be safe and healthpromoting. Citrus fruits processing wastes represent a serious problem, but they are also giving sources of materials which may be utilized in the food industry because of their valuable technological and nutritional properties. The aim of this study was to use the defatted powder of Baladi orange (Citrus sinensis) peels in preparing of low caloric sponge cake. Defatted orange peels powder, added at different levels $(0 ; 2.5$, $5.0 ; 7.5$ and $10 \%$ ), to sponge cake mixture. The influence of using such levels of orange peels fiber on sponge cake as follow: with more adding levels of defatted orange peels powder the moisture, ether extract and total carbohydrate contents were decreased, while crude protein, crude fiber, and minerals ( $\mathrm{Fe}, \mathrm{K}, \mathrm{Na}, \mathrm{Ca}$ and $\mathrm{P}$ ) contents were increased except zinc. Also the energy was decreased. Microbiological examination including total viable count, moulds and yeast were decreased with adding more orange peels powder. The addition levels of defatted orange peels powder increased yellowness of the prepared cakes. Sensory evaluation of manufactured cakes indicated that using of the defatted Baladi orange peels powder at $7.5 \%$ level was good enough comparing with control cake. Finally, it could be recommended that the defatted orange peels can be utilized in making sponge cakes until $7.5 \%$ substitution levels with wheat flour to solve some of health problems.
\end{abstract}

Keywords: Citrus wastes; Baladi orange; Sponge cake and Nutritional value

\section{INTRODUCTION}

Citrus are considered one of the most important fruits and orange (Citrus sinensis) is the predominate type of citrus grown in Egypt, which produced more than half of the total fruits production. The total annual production of Egyptian orange fruits are 1.789 million tons, which produced from 210,000 feddans (FAO, 2009). During processing and preparation of orange fruits, large qualities of wastes (about 50\%) are discarded and disposal of these waste materials becomes difficult and causes serious problems (El-Bastawesy, 1999). Peel are the most important wastes remaining after the processing of orange fruits. Albedo is a white, spongy and cellulosic tissue which is the principal citrus peel component. Due to its high fiber content albedo could considered as a potential fiber source (PerezAlvarez et al., 2002). Citrus wastes have high water content $(80 \%)$ which make difficult to be utilized in food industries. So it is necessary, for their processing to obtain a powder (7\% water) with a high fiber content as given by Fernandez-Gines, et al. (2004) also, they mentioned a process for the preparation of citrus fibers using the orange peel as a raw material. Hence, it 
is necessary to find a feasible way to utilize the peels to have a positive environmental impact or to turn them into useful products (Manthey and Grohmann, 1996). Therefore, this study was carried out as a source of functional compounds in bakery products.

\section{MATERIALS AND METHODS}

\section{Materials}

Sheikh City.

Baladi oranges was purchased from the local fruits market at Kafr El-

\section{Methods}

Preparation of orange peels

The peels were stripped with a paring knife. The orange peels were cut into small pieces using a Tiffiny Fruit processor (Model: Mini Food Processor No MC9, Tiffiny) and were sealed in glass bottles. The flavedo and albedo from four oranges were well mixed within each (flavedo and albedo) sample, separately.

\section{Preparation of defatted orange peels powder:}

Orange peels were prepared by packing fresh raw material in $2 \mathrm{~kg}$ pouches and promptly frozen to $-30 \stackrel{\circ}{\circ} \mathrm{C}$ until further use. After thawing (24 $\mathrm{h} / 2-5^{\circ} \mathrm{C}$ ) the peels were pressed using an helical press to remove excess liquid prior to drying. Then drying in an oven at $50 \pm 5 \stackrel{\circ}{\circ} \mathrm{C}$ during $24 \mathrm{~h}$ to improve the peels shelf life without addition of any chemical preservative. Ether extract of orange peels were extracted by petroleum ether $\left(40^{\circ}-60^{\circ} \mathrm{C}\right)$ for 8 hours. A grinder mill and sieves were used to obtain a powder particle size of less than $0.417 \mathrm{~mm}$. then, packed and stored at $4^{\circ} \mathrm{C}$ until used.

\section{Preparation of sponge cake:}

The sponge cake was prepared according to El-Masry et al. (1990) of wheat flour $(72 \%)$, flour was replaced by defatted orange peel powders at the levels of $0,2.5,5.0,7.5$ and $10 \%$ for each., $200 \mathrm{~g}$. eggs, $120 \mathrm{~g}$. yoghurt, $20 \mathrm{~g}$ baking powder, $0.5 \mathrm{~g}$. vanilla and $170 \mathrm{~g}$. sugar, The sugar was mixed with homogenate eggs and yoghurt that containing vanilla for $20 \mathrm{~min}$. using standard mixer. Wheat flour and baking powder were added in small portion and mixed for $5 \mathrm{~min}$., five hundreds gram of butter were weighted into baking pans and backed at $250^{\circ} \mathrm{C}$ for 30 minutes.

\section{Analytical methods:}

Moisture, ash, ether extract, crude protein, crude fiber and non protein nitrogen were determined according to the methods of A.O.A.C.(2000). Carbohydrate content was determined by differences 100 (ash + ether extract + crude protein + crude fiber). Minerals content was determined by digestion of $0.5 \mathrm{~g}$ of samples in $10 \mathrm{ml} \mathrm{of} \mathrm{H}_{2} \mathrm{SO}_{4}$ and one $\mathrm{ml}$ perchloric acid in a conical flasks (A.O.A.C, 2000). Phosphorus was determined according to Carter (1993). Calcium, sodium and potassium were determined by Sherwood, flame photometer,410 according to Black (1983). Total iron and zinc were determined using atomic absorption spectrophotometer (mode Avanta) as given by Chapman and Pratt (1961). 


\section{Microbiological examination:}

Samples were prepared using the methods of Anonymous (1996). Total viable bacteria, molds, yeasts, Coliform bacterial, were carried out according to the methods as given by Kiss, (1984).

\section{Ink print texture of Cake:}

Ink print texture test of sponge cake prepared from wheat flour (Control) and other mixtures was measured according to the methods described by Metwalli (1989).

\section{Physical properties:}

Sponge cake volume $(\mathrm{Cm} 3)$ was measured by rapeseed displacement and the volume was estimated as described by the A. A. C. C. (1990), specific lightness and moisture absorption for cake of sponge cake was conducted according to Kramer and Twigg (1973) method, calculated using the following equation:

$$
\text { Specific lightness }=\frac{\text { Volume of cake }}{\text { Weight of cake }}
$$

The $\mathrm{pH}$ values of hydrolysate and fermentation broth were measured according to the A.O.A.C. (2000), using digital pH-meter (Jenway, model, 3010) with glass electrode at room temperature.

\section{Energy values (Caloric values)}

Energy values were calculated according to Lawrence (1965) using the following equation: Energy value $(\mathrm{Kcal} / 100 \mathrm{~g})=($ protein content $\times 4)+($ fat content $\times 9)+($ carbohydrate content $\times 4)$.

\section{Daily needs of energy and protein:}

Grams consumed of food to cover the daily needs of energy and protein for adult (25-50 year) were calculated using the daily requirements for adult (2900 Cal/day) as given by Anonymous (1989). The GDR of energy (g) calculated using the following two equations reported by Anonymous (1985).

G.D.R. of energy $(\mathrm{g})=\frac{\text { Energy daily requirements of adult man }(2900 \mathrm{Cal} / \mathrm{day})}{\text { Energy value }(\mathrm{Kcal} / 100 \mathrm{~g} \text { food })}$

G.D.R. of protein $(\mathrm{g})=\frac{\text { protein daily requirements of adult man }(63 \mathrm{~g} / \text { day })}{\text { protein content }(63 \mathrm{~g} / 100 \mathrm{~g} \text { food })}$

\section{Percent satisfaction of energy and protein:}

Percent satisfaction of daily requirements of energy and protein for adult man ( $25-50$ year) when consumed $200 \mathrm{gm}$ of sample (P.S/200) were calculated using the equation reported by Anonymous (1985).

$$
\begin{gathered}
\text { P.S.of energy }(\%)=\frac{200 \mathrm{X} \text { Energy value }(\mathrm{Kca} / 100 \mathrm{~g} \text { sample })}{\text { Energy daily requirements of adult }(2900 \mathrm{Cal} / \text { day })} \mathrm{X} 100 \\
\text { P.S.of protein }(\%)=\frac{200 \mathrm{X} \text { g protein } / 100 \mathrm{~g} \text { sample }}{\text { protein requirements of adult }(\mathrm{g} / \text { day })} \mathrm{X} 100
\end{gathered}
$$




\section{Sensory evaluation of prepared foods:}

The sensory properties of cakes containing orange peel powder were evaluated for their color, appearance, odor, texture, taste and overall acceptability on a one to ten hedonic scale, where excellent (9-10), very good (6-8), fair (4-5) and not acceptable (2-3) as described by El-Sheikh (1999).

\section{Statistical analysis:}

The data were analyzed according to Steel and Torrie (1980). One way analysis of analysis of variance (ANOVA) using the general linear models procedure was used to test for main effects where more than two variables being compared. Differences with $P$ values $\leq 0.05$ were considered to be statistically significant.

\section{RESULTS AND DISCUSSION}

\section{Proximate chemical compositions of fresh orange peels:}

The peels of Baladi orange were chemically analyzed for its contents of moisture, ash, crude protein, ether extract, crude fiber and total carbohydrates. The obtained data are presented in Table (1). The obtained results indicate that fresh orange peels contained, 76.44, 5.80, 8.85, 5.99, 62.93 and $16.44 \%$ for moisture, ash, crude protein, ether extract, crude fiber and total carbohydrates (on dry weight basis), respectively. Such findings coincide those reported by (Hamed, 1985; Silva et al., 1997 and El-Hendy, 2003).

Table (1): Chemical composition of fresh orange peel (on dry weight basis).

\begin{tabular}{|l|c|}
\hline \multicolumn{1}{|c|}{ Component } & $(\%)$ \\
\hline Moisture & 76.44 \\
\hline Dry Matter & 23.56 \\
\hline Ash content & 5.8 \\
\hline Crude protein & 8.85 \\
\hline Ether Extract & 5.99 \\
\hline Crude fiber & 62.93 \\
\hline Total Carbohydrate & 16.44 \\
\hline Minerals content (mgL100g) & 2.36 \\
\hline Iron (Fe) & 0.07 \\
\hline Zinc (Zn) & 10.20 \\
\hline Potassium (K) & 7.02 \\
\hline Sodium (Na) & 27.00 \\
\hline Calcium (Ca) & 20.37 \\
\hline Phosphorus (P) & \\
\hline
\end{tabular}

Regarding to minerals contents of peels of Baladi orange, it should be noted that calcium $(27.00 \mathrm{mg} / \mathrm{g})$ was the highest content of minerals. On the other hand the peels contained high amounts of phosphorus, potassium, sodium, iron and traces amount of zinc $(0.07 \mathrm{mg} / \mathrm{g})$. 
Hamed (1985) noticed that the chemical composition of citrus peels are affected by many factors such as variety, place of origin, seasonal and climatic variations.

Effect of substituting orange peels powder with different levels on the chemical composition and mineral contents of sponge cake:

The effect of substituting orange peels powder with different levels $(2.5,5,7.5$ and $10 \%)$ on chemical compositions and mineral contents of sponge cake are shown in Table (2). Increasing the levels of orange peels powder caused a decreased in moisture, ether extract and total carbohydrates, while crude fiber was increased. On the same time ash content was not affected by adding orange peels powder. This results indicate to the substituting of defatted orange peels powder which cause reducing in the moisture, ether extract and total carbohydrate contents. Elsaid et al., (1990); Ibrahim et al., (1990) reported that many forms of dietary fiber have been added to bread and other cereal based-products. It is possible to formulate satisfactory high fiber breads (15-20\% cellulose) wheat bran and oat bran are used in bread making.

Table (2): Effect of using different defatted orange peels powder levels on chemical composition of sponge cake (on dry weight basis).

\begin{tabular}{|l|c|c|c|c|c|}
\hline \multirow{2}{*}{ Component } & \multicolumn{5}{|c|}{ Defatted orange peels powder } \\
\cline { 2 - 6 } & Control & $\mathbf{2 . 5 \%}$ & $\mathbf{5 \%}$ & $\mathbf{7 . 5 \%}$ & $\mathbf{1 0 \%}$ \\
\hline Moisture & 78.09 & 73.86 & 75.00 & 73.60 & 74.20 \\
\hline Dry Matter & 21.91 & 26.14 & 25.00 & 26.40 & 25.80 \\
\hline Ash content & 0.72 & 0.75 & 0.77 & 0.78 & 0.80 \\
\hline Crude protein & 2.40 & 2.68 & 2.84 & 3.06 & 3.29 \\
\hline Ether Extract & 37.24 & 37.09 & 36.93 & 36.79 & 36.63 \\
\hline Crude fiber & 1.36 & 3.01 & 4.69 & 6.32 & 7.98 \\
\hline Total Carbohydrate & 58.80 & 56.47 & 54.77 & 53.05 & 51.30 \\
\hline Total calories(Kcal/100g) & 579.96 & 570.41 & 562.81 & 555.55 & 548.03 \\
\hline Minerals content (mg/100g) & & & & & \\
Iron (Fe) & 9.01 & 9.07 & 9.15 & 9.21 & 9.24 \\
\hline Zinc (Zn) & 0.13 & 0.12 & 0.12 & 0.07 & 0.7 \\
\hline Potassium (K) & 3.2 & 4.8 & 4.8 & 4 & 4 \\
\hline Sodium (Na) & 10.7 & 11.5 & 11.5 & 12.3 & 12.3 \\
\hline Calcium (Ca) & 13.33 & 14.44 & 15.56 & 15.56 & 16.62 \\
\hline Phosphorus (P) & 14.7 & 15.30 & 15.81 & 16.01 & 16.71 \\
\hline Ca/P ratio & 0.91 & 0.94 & 0.98 & 0.97 & 0.99 \\
\hline K/Na ratio & 0.30 & 0.03 & 0.03 & 0.02 & 0.02 \\
\hline
\end{tabular}

However, increasing levels of orange peel powder induce the mineral contents ( $\mathrm{Fe}, \mathrm{K}, \mathrm{Na}, \mathrm{Ca}$ and $\mathrm{P}$ ) except zinc which seem to be decreased. Ishida et al.,(2000) stated that, one mg/day of iron is suitable for adults to maintain the daily balance of intake and excretion. Thus, all samples contain suitable amounts of iron. Shills and Young (1988) reported that if $\mathrm{Ca} / \mathrm{P}$ ratio is lower than 0.5 , high amount of calcium may be loss in urine, resulting a decrease in the calcium levels of bones. In this relation, $\mathrm{Ca} / \mathrm{P}$ ratio of tested sponge cakes were good source of minerals required for bones formation and 
when the orange peel powder levels were increasing, the $\mathrm{Ca} / \mathrm{P}$ ratio was induce. A K/Na ratio in diet is an important factor in prevention of hypertension and arteriosclerosis, since $\mathrm{K}$ depresses and $\mathrm{Na}$ enhances blood pressure (Yoshimura et al., 1991). Results indicated that with increasing levels of orange peels powder the $\mathrm{K} / \mathrm{Na}$ ratio seem to be lower, however $\mathrm{K} / \mathrm{Na}$ ratio was low and that could be cause blood pressure thus it must supplemented the sponge cake with potassium

Effect of substituting orange peels powder with different levels on some physical properties of sponge cakes:

Data in Table (3) show some physical properties of backed sponge cake produced using different substitute on levels of orange peels powder. The volume $\left(\mathrm{cm}^{3}\right)$ of the backed sponge cake was decreased with increasing the orange peels powder percentage in the formula. This effect may be attributed to the dilution of the structure forming components by sugar as clarified by Kulp et al., (1991). Also as shown in Table (3), substitution of wheat flour with different levels of orange peels powder caused slight decrease in the specific lightness. These findings may be related to the increment of bulking agent in cake butter as a result of adding sweeteners during the baking process as explained by Labell, (1992).

Table (3): Effect of using different orange peels powder levels on some physical properties of sponge cakes.

\begin{tabular}{|c|c|c|c|}
\hline $\begin{array}{c}\text { Orange peel powder } \\
\text { Substitution level \% of flour }\end{array}$ & Weight (Gm) & Volume (Cm3) & $\begin{array}{c}\text { Specific } \\
\text { lightness }\end{array}$ \\
\hline Control & 440 & 1250 & 0.352 \\
\hline 2.5 & 430 & 1120 & 0.384 \\
\hline 5.0 & 450 & 1210 & 0.372 \\
\hline 7.5 & 455 & 1200 & 0.379 \\
\hline 10 & 440 & 1090 & 0.404 \\
\hline
\end{tabular}

Effect of substituting orange peels powder with different levels nutritive values of sponge cake:

The calculated nutritive values for protein and energy (Table 4) show that the energy value of backed sponge cakes upon of level $10 \%$ defatted orange peels powder.

Concerning to grams of cakes consumed to cover the daily needs of protein or energy (G.D.R), the results indicate that the values for protein and energy were lower than other samples. The percent satisfaction of the daily requirements of protein for adult when consuming $200 \mathrm{gm}$ of cakes (P.S/200) was higher than the control sample. The PS/200 for energy of all cake samples were not noticeably differ exception the control sponge cakes. On the other hand, the energy values were decreased in all samples which containing defatted orange peels powder. These results agreement with this reported by Mckee and Latner (2000), mentioned that the citrus fiber had a low caloric content, high water holding capacity and high oil absorption properties. 
Table (4): Nutritive value of cakes made using different levels of orange peels powder .

\begin{tabular}{|c|c|c|c|c|c|}
\hline \multirow{2}{*}{$\begin{array}{c}\text { Substitution } \\
\text { levels (\%) }\end{array}$} & Kcal/100g & $\begin{array}{c}\text { G.D.R } \\
\text { for protein } \\
\text { (g) }\end{array}$ & $\begin{array}{c}\text { P.S./200 } \\
\text { for protein } \\
(\%)\end{array}$ & $\begin{array}{c}\text { G.D.R } \\
\text { for energy } \\
(\mathbf{g})\end{array}$ & $\begin{array}{c}\text { P.S./200 } \\
\text { for energy } \\
(\%)\end{array}$ \\
\hline Control & 579.96 & 263.00 & 76.00 & 5000.00 & 40.00 \\
\hline 2.5 & 570.41 & 235.00 & 85.00 & 5084.00 & 39.00 \\
\hline 5.0 & 562.81 & 222.00 & 90.00 & 5153.00 & 39.00 \\
\hline 7.5 & 555.55 & 206.00 & 97.00 & 5220.00 & 38.00 \\
\hline 10 & 548.03 & 191.00 & 104.00 & 5292.00 & 38.00 \\
\hline
\end{tabular}

G.D.R: Gram consumed of food to cover the daily needs of protein or energy for adult man.

P.S./200: Percent satisfaction of the daily requirements of protein or energy for adult man when consumed $200 \mathrm{gm}$ of food.

\section{Effect of substituting orange peels powder with different levels on Microbial counts:}

The Effect of substituting orange peel powder with different levels of flour on microbial counts were listed in Table (5). Data show that substituting orange peels decreased the total viable bacteria, moulds and yeasts counts. El-Sharnouby et,al., (2003) noticed that, the adding of lime or orange peel fiber lead to prolong the shelf life of toast bread during one to five days of storage period at room temperature. Also with increasing the levels of orange peels powder, the tested microbial counts was decreased. Grohmann and Baldwin, (1994) reported that citrus peel oil composition primarily limonene are very inhibitory to yeast and bacterial fermentations. On the same time the coliform bacterial was not detected in all tested samples.

Table (5): Microbial examination of sponge cakes prepared using different ratios of orange peel powder as substitutes of flour after cold stored (at $4 \pm 1^{\circ} \mathrm{C}$ for one week).

\begin{tabular}{|l|c|c|c|c|c|}
\hline \multirow{2}{*}{ Substitution } & \multicolumn{5}{c|}{ Microbial count (cfu) } \\
\cline { 2 - 6 } Microorganisms & Control & $\mathbf{2 . 5 \%}$ & $\mathbf{5 \%}$ & $\mathbf{7 . 5}$ & $\mathbf{1 0 \%}$ \\
\hline Total viable count $\times 10^{2}$ & 1.15 & 1.10 & 1.05 & 1.01 & 0.90 \\
\hline Moulds and yeasts count $\times 10^{2}$ & 0.99 & 0.96 & 0.94 & 0.85 & 0.78 \\
\hline Coliform count $\times 10^{2}$ & Nil & Nil & Nil & Nil & Nil \\
\hline
\end{tabular}

\section{Sponginess of cake made using defatted orange peels powder:}

The sponginess of cake prepared using various levels of defatted orange peels powder was illustrated in Figures (1,2,3,4 and 5). It is clear from these figures that the cake samples made using different ratios of defatted orange peels powder as substitution of wheat flour had lower sponginess and big unregulated cells compared with control samples. In addition, the pictures in the same Figures $(6,7,8,9$ and 10) show that the texture of cake was affected by adding of defatted orange peels powder as replacement of wheat flour, the crump cell walls became thicker and more compact especially with these prepared using peels meal. It could be also observed that the sponginess and cells regulation of cake decreased with increasing of substitution ratio. 


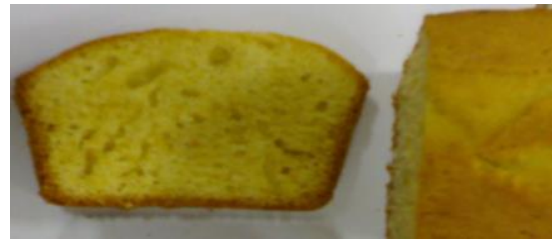

Fig. (1): Control sponge cake
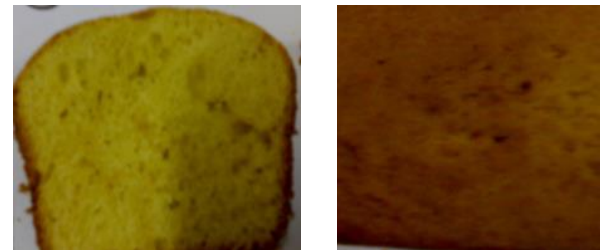

Fig. (3): Sponge cake substituted with $5 \%$ of defatted orange peel powder

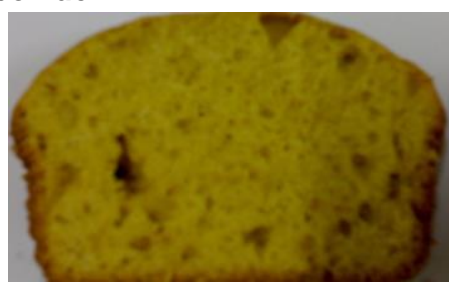

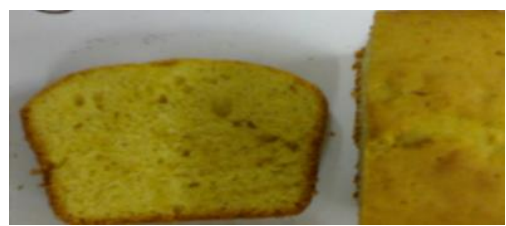

Fig. (2): Sponge cake substituted with $2.5 \%$ of defatted orange peel powder

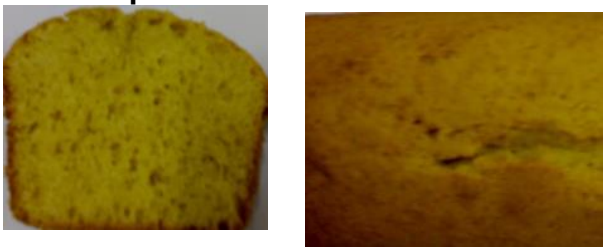

Fig. (4): Sponge cake substituted with $7.5 \%$ of defatted orange peel powder

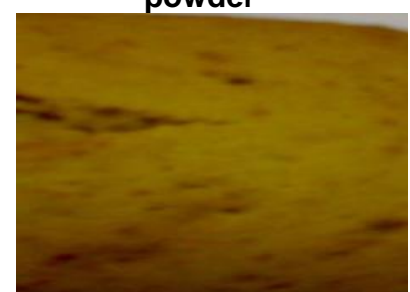

Fig. (5): Sponge cake substituted with $10 \%$ of defatted orange peel powder

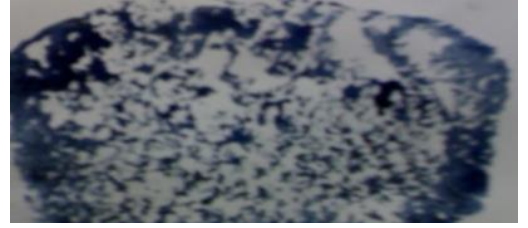

Fig. (6): Ink print of crump cell of control sponge cake

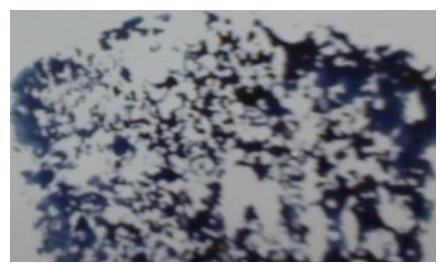

Fig. (8): Ink print of crump cell of sponge cake substituted with $5 \%$ of defatted orange peel powder

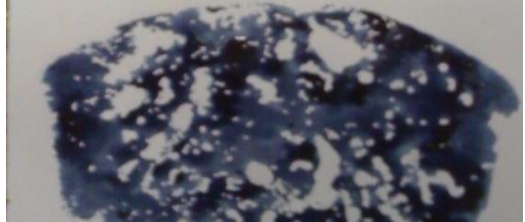

Fig. (7): Ink print of crump cell of sponge cake substituted with $2.5 \%$ of defatted orange peel powder

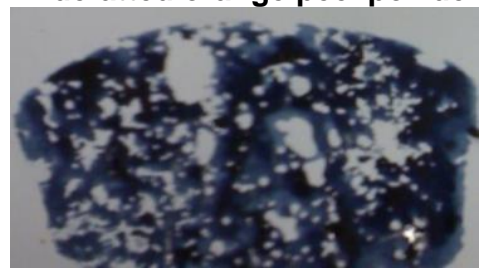

Fig. (9): Ink print of crump cell of sponge cake substituted with $7.5 \%$ of defatted orange peel powder 


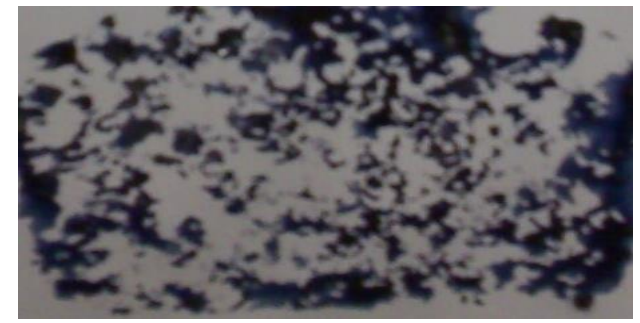

Fig. (10): Ink print of crump cell of sponge cake substituted with $10 \%$ of defatted orange peel powder

\section{Sensory evaluation of cakes contained orange peels powder in different substitution percent of flour:}

Sensory evaluation is still the most satisfactory way of assessing the quality of many products. In all foods, organoleptic tests are generally the final guide to its quality from the consumer point view. Organoleptic evaluation of cakes usually covers color, appearance, taste, odor and less extent its texture (El-Sheikh, 1999). In this investigation sponge cakes in all treatments, immediately after processing were evaluated organoleptically by 20 panelists. Both of Organoleptic properties were evaluated in comparison with cake prepared with wheat flour only.

Results (Table 6) indicate that values as mean of the scores given by 20 panelists based on a 9-point scale.. From the tabulated results, it could be noticed that data indicate that sponge cakes produced with wheat flour (control) and this with a substitute ratio of $(2.5 \%)$ have relatively the best appearance, color, taste, odor, texture and overall acceptability when comparing with the other manufactured cakes The statistical analysis supports these findings at $P \leq 0.05$.

Table (6): Organoleptic properties of fresh cakes prepared using different ratios of orange peels powder as substitutes of flour.

\begin{tabular}{|c|c|c|c|c|c|c|}
\hline \multirow{2}{*}{$\begin{array}{c}\text { Substitution } \\
(\%)\end{array}$} & \multicolumn{6}{|c|}{ Organoleptic score } \\
\hline & Color & Texture & $\begin{array}{c}\text { Crumb } \\
\text { color }\end{array}$ & Odor & Taste & $\begin{array}{c}\text { Overall } \\
\text { acceptability }\end{array}$ \\
\hline Control $^{a}$ & $8.6 \pm 0.04^{a}$ & $9.3 \pm 0.043^{a}$ & $8.7 \pm 0.18^{\mathrm{a}}$ & $8.0 \pm 0.04$ & $8.3 \pm 0.04$ & $8.58^{a}$ \\
\hline $2.5^{\mathrm{b}}$ & $8.6 \pm 0.03^{a b}$ & $8.6 \pm 0.02^{b}$ & $8.6 \pm 0.32^{a}$ & $8.6 \pm 0.02$ & $8.3 \pm 0.04$ & $8.54^{a b}$ \\
\hline $5.0^{b}$ & $8.7 \pm 0.03^{a b}$ & $8.5 \pm 0.03^{\mathrm{ab}}$ & $8.1 \pm 0.26^{\mathrm{ab}}$ & $8.6 \pm 0.03$ & $7.1 \pm 0.01$ & $8.2^{\mathrm{b}}$ \\
\hline $7.5^{\mathrm{abc}}$ & $8.6 \pm 0.04^{a b}$ & $8.0 \pm 0.04^{\mathrm{ab}}$ & $8.1 \pm 0.03^{a b}$ & $7.7 \pm 0.06$ & $7.6 \pm 0.08$ & $8.00^{c}$ \\
\hline $10^{c}$ & $8.0 \pm 0.04^{b}$ & $7.0 \pm 0.04^{b}$ & $7.6 \pm 0.04^{b}$ & $8.1 \pm 0.04$ & $7.4 \pm 0.05$ & $7.62^{d}$ \\
\hline Significance & * & ** & * & NS & NS & * \\
\hline
\end{tabular}

**: $\mathbf{P} \leq 0.01$.

*: $P \leq 0.05$.

NS: Non significant

$(A)$ and $(B)$ : comparison of means of scores by sweetener type.

$A, b$ and $c$ : comparison of means of scores by substitute ratio.

Overall acceptability = (Appearance + Texture + Color + Odor + Taste $)$ divided by 5 . 
The obtained results are in agreement with those obtained by El-Sheikh (1999). Regarding to the attained results, it could be concluded that, all these products had scores more than 5, showing that all samples were organoleptically accepted.

\section{REFERENCES}

Abdel-Nabey A.A. and Attia, R.S. (1998). Physical properties and chemical composition of cataloup seeds as an unexplotted source of vegetable oil. Menofiya J. Agric. Res., 23:991-1007.

Abdi, A. And Ibrahim, S. (2001). Egypt Annual Production of Citrus. Gain Report Foregn Agricultural Service, United States Department of Agricultural (USDA), Washington, DC, USA.

A.A.C.C., American Association of Cereal Chemists (1990). Approved Methods of the American Association of Cereal Chemists. Inc., st. Paul, MN, USA.

Anonymous (1996). American Public Health Association Washington D.C., Compendium of method for the microbiological examination of food, Ed Speack M.L. AHPA, New York, USA, p701.

AOAC (2000). Association of official analytical chemists, Official methods of analysis.; $17^{\text {Th }}$ ed. Washington, DC., USA.

Black, C.A. (1983). Methods of soil analysis. Soil Sci. Soc., Amer. Inc. Pul. Modison, Wisconsin USA.

Carter, M.R. (1993). Soil sampling and methods of Analysis. Condian Soc. Soil Sci., Lewis londen, Tokyo.

Chapman, H.D. and Pratt, P.F. (1961). Methods of analysis for soils, plant and water. Univ. of California, USA.

El-Bastawesy, A. M. (1999). Studies on pectin. Ph.D. Thesis, Food Indu. Dept., Fac. of Agric., El-Mansoura Univ., Egypt.

El-Hendy, W. M. (2003). Chemical and technological Studies on Some Foods. Chemical, Nutritional and Technological Evaluation of $\beta$ carotene Extracted from Some Citrus Peels. Ph. D. Thesis, Food Sci. Dept., Fac. Agric., Tanta Univ., Egypt.

El-Masry, E. A.; Youssef, M. M. and Shekib, L. A. (1990). Development of special cakes for obese and diabetic subjects utilizing sugar substitute. The first Alex. Conference on Food Science and Technology, Fac. of Agric. Alex. Univ., 3: 137.

Elsaid,A.A.; El-Barding,A.; El-Sayed B.,M. and Attia,T.(1990). Thechnological studies on high fiber cake. Bull Nutr. Inst. Cairo. Egypt, 10 (4): 95.

El-Sharnouby, S. A. (2003). Evaluation of some physical, chemical and nutritional characteristics of some Egyptian citrus seeds. J Agric. Sci. Mansoura Univ., 28 (9): 6795 - 6806.

El-Sheikh, D. M. (1999). Production and evaluation of some low caloric jams. Ph. D. Thesis, Food Technology Dept., Fac. of Agric., Cairo Univ.

Anonymous (1985). FAO/WHO.UNU. Energy and protein requirements report of a joint FAO/WHO/UNU expert consultation, World Health Organization, Tech. Dep., Series, No. 742, WHO, Geneva, Switzerland. 
FAO, (2009). Food and Agriculture Organization of the United Nations . orange production in Egypt. www.fao.org

Fernandez-Gines, J. M.; Fernandez-Lopez, J.; Sayas-Barbera E.; Sendra E. and Perez-Alvarez J.A. (2004). Lemon albedo as a new source of dietary fiber: application to bologna sausage. Meat Science, 76,7-13.

Grohmann K, and Baldwin E., (1994). Fermentation of galacturonic acid and other sugars in orange peel hydrolysates by the ethanologenic strain of E. coli . Biotechnology Letters, Vol. 16 No. 3 pp:281-286.

Hamed, H. S. (1985). Studies on Utilization of Some Cannery Wastes (Carotenoids of Orange Flavedo). Ph. D. Thesis, Food Sci. Dept., Fac. Agric., Cairo Univ., Egypt.

Ibrahim, N. A.; Fahmy, A. H. and Afaf, A. A.(1990). Production of new reduced caloric bread. 1- Effect of alpha cellulose on dough rheology and bread properties. International conference on foods for special dietry and medicinal uses. March (19-22) Cairo, Egypt.

Ishida, H.; H. Suzuno; N. Sugiyama; S. Innami; T. Todokoro and A. Maekawa, (2000). Nutritional evaluation of chemical component of leaves stalks and stems of sweet potatoes (Ipomoea batatas poir). Food Chemistry. 68: 359-367.

Kiss, I. (1984). Testing methods in food microbiology. Elsevir- Amsterdam Oxford-New york - Tokoy.

Kramer, A. and Twigg, B. A. (1973). Quality control for food industry. The AVI Publ. Comp., INC, Westport, Connecticut, USA.

Kulp, K. Lorenz, K. and Stone, M. (1991). Functionality of carbohydrate ingredient in bakery products. Food Technol. 3:136.

Labell, F. (1992). Low caloric tuber flour for pasta backed goods, Food Process 53(4):56-58.

Larrauri, J. A. (1999). New approaches in the preparation of high dietary fibre powders from fruit by-products. Trends in Food Science \&Technology, 10,3-8.

Lawrence, R.D. (1965). "The diabetic life" J. and A. churchill, LTD. London.

Manthey, J. A. and Grohmann, K. (1996). Concentrations of hesperidin and other orange peel flavonoids in citrus processing byproducts, J. Agric. Food Chem. 44 (3) 811-814.

Mckee L.H. and Latner T.A. (2000). Underutilized sources of dietary fiber: A review. Plant Foods for Human Nutrition 55:285-304.

Metwalli, S. M. (1989). Acomparative study of functional properties of three raw and frozen egg varities. J. Agric. Sci. Mansoura Univ., 14 (1): 280 287.

Anonymous (1989). Recommended dietary allowances. National Research Council of Food and Nutrition. Board-National, Academy of Sciences, Revised Washington, D.C., USA.

Perez-Alvarez, J.; A., Fernandez-Lopez; J., Sayas-Barbera; E. Navarro; Prakongpan, T.; Nitithamyong, A. and Luangpituksa, P. (2002). Extraction and Application of dietary fiber and cellulose from pineapple cores. Journal of Food Science, 67, 1308-1313. 
Saura-Calixto F. (1993). Apple dietary fiber: to news types of high quality fibers, Alimentaria 242,57-61

Shills, M.E. and V.R. Young,(1988). Modern nutrition in health and disease. In Nutrition, D. C. Neiman, D. E., Buthepodorth and C. N. Nieman (ed), WmC. Brown Publishers Dubugue, USA, pp: 276-282.

Silva, A.G.; Wanderley, R.C., Pedr;oso, A.F. and Ashbell, G. (1997). Ruminal digestion kinetics of citrus peel. Animal Feed Sci., Tech., 68:247-257.

Steel, R. G. and Torrie, J. H. (1980). Principles and procedures of statistics. 2 nd ed. pp 120. Mc Graw-Hill, New York, USA.

Yoshimura, M., H.Takahashi and T.Nakanishi. (1991). Role of sodium, potassium, calcium, magnesium on blood pressure regulation and antihypertensive dietary therapy. Japanese Journal of Nutrition, 49: 5362.

$$
\begin{aligned}
& \text { استخدام قشور البرتقال البلدي لإنتاج كيك إسفنجي منخفض السعرات المئر الحرارية }
\end{aligned}
$$

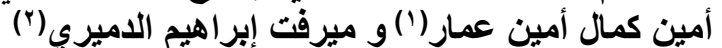

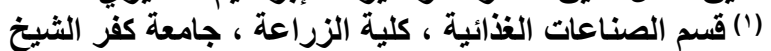

$$
\begin{aligned}
& \text { (†) قسم الاقتصاد المنزلي ، كلية التربية النوعية ، جامعة كفر الثيخ }
\end{aligned}
$$

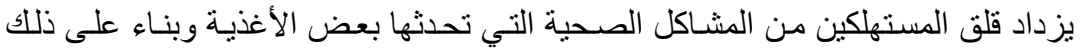

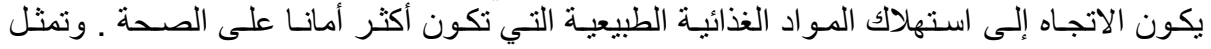

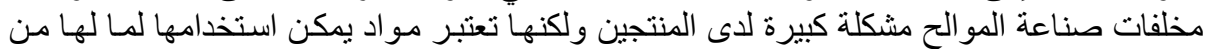

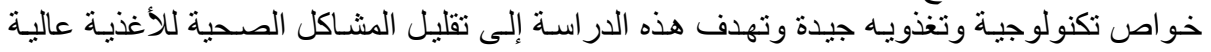

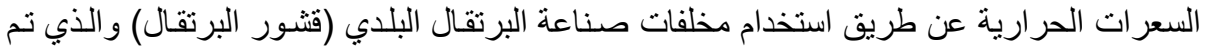

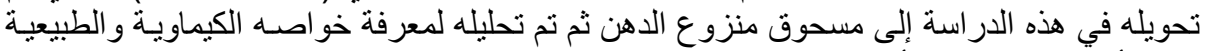

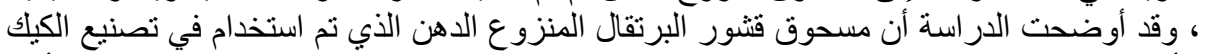

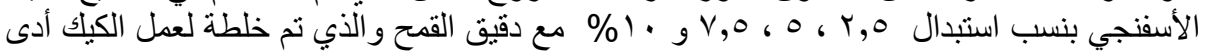

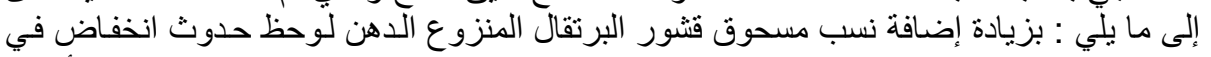

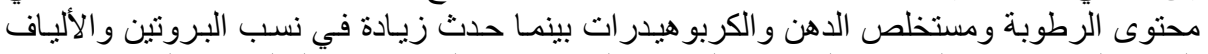

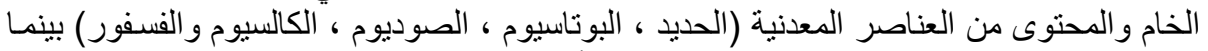

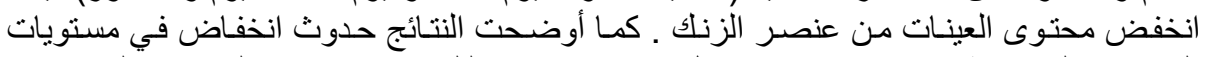

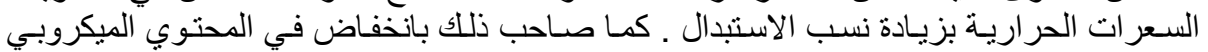

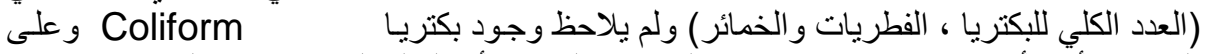

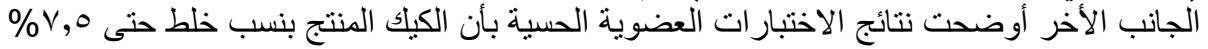

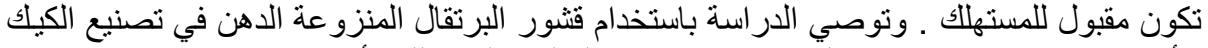

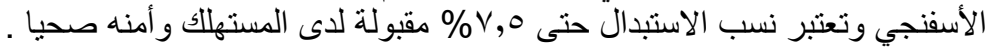

